\title{
Orosz-török energiapolitikai kapcsolatok 2019 tavaszán: a folyamatban lévő stratégiai energiaprojektek értékelése ${ }^{1}$
}

\begin{abstract}
A tanulmány az orosz-török kapcsolatokat vizsgálja az energiapolitika területén. Törökország hagyományosan nagymértékben energiaimport-függő, és különösen függ az orosz földgáz importjától. Az elemzés a két legjelentősebb folyamatban lévő török-orosz energiaprojektet (a Török Áramlat földgázvezeték és az Akkuyu atomerőmü projektjét) értékeli. Ez alapján arra a következtetésre jut, hogy az említett projektek nem fognak jelentős változást hozni sem Törökország és Oroszország kapcsolatában, sem pedig Ankara nyugati stratégiai orientációjában.
\end{abstract}

Kulcsszavak: Oroszország, Törökország, energiapolitika, Török Áramlat, atomenergia

\section{Pénzváltó Nikolett: Russian-Turkish Energy Policy Relations in the Spring of 2019: The Evaluation of the Ongoing Energy Policy Projects}

The study examines the relationship of Turkey and Russia in the field of energy policy. Turkey has historically been highly dependent on energy imports, especially on the natural gas import from Russia. The paper evaluates the two most significant ongoing Turkish-Russian energy projects (TurkStream natural gas pipeline and Akkuyu Nuclear Power Plant). Thus, it concludes that these projects will not be real game changers: they will neither significantly transform the relationship of Turkey and Russia nor will they effect the Western strategic orientation of Ankara.

Keywords: Russia, Turkey, energy policy, TurkStream, nuclear energy

\section{Bevezetés}

A török-orosz energiapolitikai kapcsolatok alakulása kiemelt érdeklődésre tart számot. ${ }^{2}$ 2018 folyamán több fontos fejlemény történt a területen, ez teszi indokolttá jelen tanulmányt. Az elemzés röviden áttekinti Oroszország helyét a török energiaellátásban, majd a két legjelentősebb orosz-török energiaprojekt, az Akkuyu atomerőmű és a Török Áramlat földgázvezeték szerepét értékeli. Két fő kérdésre keressük a választ: 1. várhatóan milyen

\footnotetext{
Ez a cikk a Nemzeti Kutatási, Fejlesztési és Innovációs Hivatal 129243-as számú, „Hagyomány és rugalmasság Oroszország biztonság-és védelempolitikájában” címü kutatási pályázatának támogatásával valósult meg.

2 Köztük a magyar kutatók körében is. Lásd például: DuDlák Tamás: Törökország helye az Európai Unió, Oroszország és Azerbajdzsán közti gázjátszmában, Világpolitika, 2. évf., 2017/1, 60-90. o.; KozmA Tamás: A török-orosz kapcsolatok energiadiplomáciai aspektusai. In: BARANYi Tamás Péter - SzÁLKai Kinga (szerk.): Újhold. A török külpolitika útkeresése a 21. század elején, Antall József Tudásközpont, 2016, 166-187. o.; ToNGori Zsófia: A Török Áramlat gázvezeték és Törökország vezetékes gázszállításban rejlő potenciális lehetőségei. Energiabiztonsági dilemmák a Török Áramlat gázvezetékkel kapcsolatban, Hadtudományi Szemle, 10. évf., 2017/1, 168-183. o.
} 
mértékben változik a török függés az orosz energiahordozóktól, illetve 2. milyen következtetéseket vonhatunk le a török-orosz energiapolitikai együttmüködésből Törökország külpolitikai orientációjára nézve.

\section{Oroszország szerepe a török energiaellátásban}

A török energiapiac két fö jellemzője a folyamatosan növekvő energiaszükséglet és a nagyfokú importfüggőség. A török villamosenergia-igény 2002 óta évente átlagosan 5,5\%-kal növekszik, ami a legnagyobb növekedési ütem az OECD államai közül. ${ }^{3}$ Törökország a Világbank adatai szerint 2015-ben energiafelhasználásának 75,2\%-át importból fedezte. Az ország 2018-ban 42,99 milliárd dollár értékben importált energiát. ${ }^{4}$

A török energiamix a Nemzetközi Energiaügynökség (IEA) legutóbbi, 2016-os adatai alapján a következő arányokat mutatta: kőolaj (30\%), földgáz (28\%), szén (28\%), napés geotermikus energia (6\%), vízenergia (4\%), bioüzemanyagok és hulladék (2\%). ${ }^{5}$

Moszkva Törökország egyik legfontosabb energiaellátója. A legnagyobb török kitettség Oroszországnak a földgáz tekintetében mutatkozik meg. Törökország földgázszükségletének 99\%-át importálja. Ebből Oroszországból érkezett 2017-ben a földgáz több mint fele (51,9\%-a); ezt követte - erősen lemaradva - Irán (16,6\%), Azerbajdzsán (13,9\%) és Algéria $(9,2 \%)$. A földgáz szerepe azért is fontos, mert a török villamosenergia-termelés legjelentősebb hányada - 2007-ben még 49,6\%-a, 2017-ben már „csak” 37\%-a - földgázból származik. ${ }^{6}$ Ankara tudatosan igyekszik csökkenteni az orosz gázfüggőség mértékét, diverzifikációs lehetőségei azonban korlátozottak. ${ }^{7}$ Bár az orosz földgáz aránya a teljes török gázimporton belül folyamatosan csökkent (2006-ban 63,92\%, 2011-ben 57,91\%, 2017-ben $51,9 \%$ volt ez az arány), az orosz forrásból importált gáz mennyisége a növekvő török energiaigény következtében ezzel párhuzamosan mégis folyamatosan növekedett (2006-ban 19,3, 2011-ben 25,4, 2017-ben 28,6 milliárd $\left.\mathrm{m}^{3}\right) .{ }^{8}$ Mindez a török diverzifikáció sikerét mutatja: a növekvő import ellenére képesek voltak csökkenteni a relatív függőséget az oroszoktól.

Moszkva a török szénimportban is jelentős helyet foglal el: 2018-ban Kolumbia után (57\%) a másodikat (35\%). ${ }^{9}$ Oroszország emellett kőolaj szempontjából is fontos partner. Az oroszoknak való török kitettség ugyanakkor kevésbé erős a kőolaj, mint a földgáz esetében. Az egyes országokból importált kőolaj aránya kiegyenlítettebb: 2017-ben a kőolaj, illetve kőolajtermékek importjának 26,9\%-a Iránból, 18,8\%-a Oroszországból, 16,5\%-a

Turkey's Energy Profile and Strategy, [online], 2019. Forrás: Mfa.gov.tr [2019. 03. 24.]

Turkey's energy import bill up 15.6 percent in 2018, [online], 2019. 02. 06. Forrás: Hurriyetdailynews.com [2019. 03. 24.]

Total Primary Energy Supply (TPES) by source, Turkey 1990 - 2016, [online], 2019. Forrás: Iea.org [2019. 03. 24.]

6 Zeynel Tunc - Aslı Kehale Altunyuva: Oil and gas regulation in Turkey: overview, [online], 2018. 09. 01. Forrás: Ca.practicallaw.thomsonreuters.com [2019. 03. 24.]

7 Kozma Tamás: Diversification Dilemmas in Turkey's Natural Gas Imports, Asian Journal of Middle Eastern and Islamic Studies, 11. évf., 2017/11, 90-106. o.

8 Doğal Gaz Piyasasi 2017 Yılı Sektör Raporu, [online], 2017, T. C. Enerji Piyasası Düzenleme Kurumu. Forrás: Epdk.org.tr [2019. 03. 24.]

9 Turkey's thermal coal receipts from Russia fell by 16pct in 2018, [online], 2019. 02. 27. Forrás: Steelguru.com [2019. 03. 24.] 
Irakból, 8,2\%-a Indiából származott. ${ }^{10} \mathrm{~A}$ képet tovább árnyalja, hogy nincs közvetlen orosz-török kőolajvezeték. ${ }^{11}$ A szén és a kőolaj biztonsági aspektusa összességében csekélyebb, mivel ezek nem hálózatos szektorok.

Törökország jelenleg nem rendelkezik atomerőmüvel, a tervek szerint azonban 2023-tól új elemként fog megjelenni a nukleáris energia. Ankara három atomerőmü építését tervezi a következő években, amelyek közül az oroszok által a Földközi-tenger partján, Akkuyuban épülő erőmüre van egyedül aláírt építési szerződés, 4800 MW kapacitásra. Akkuyu a tervek szerint a török villamosenergia-szükséglet 10\%-át termeli majd meg.

Törökország jelentős mértékben függ az orosz szénhidrogénektől. Látni kell ugyanakkor azt is, hogy a török-orosz függés egy kölcsönös függőség. Az orosz gazdaságnak nagy szüksége van az energiahordozók exportjából származó bevételekre; a 2014 óta kialakult recesszió és lassú kilábalás miatt még jobban. Németország után Törökország a Gazprom második legnagyobb külföldi piaca, ami felértékeli Törökország szerepét az oroszok számára. ${ }^{12}$

Itt kell megjegyeznünk azt is, hogy a globális verseny felerősödésével (LNG, palagáz, megújuló energiaforrások) fontosabbá vált a megbízható energiaellátó képének demonstrálása, ami csökkenti a kétélü energiafegyver használatának valószínüségét Oroszország részéröl. A fentieket támasztja alá az is, hogy a török-orosz kapcsolatok közelmúltbeli mélypontja idején - a török-szíriai határ közelében repülő orosz Szu-24-es vadászgép 2015. novemberi lelövését követően - Moszkva nem vetette fel a gázszállítás felfüggesztését Törökország irányába, az egyéb széles körü gazdasági szankciók bevezetése ellenére sem. ${ }^{13}$

\section{Az Akkuyu atomerőmü}

Az Akkuyu erőmü megépítéséről az Oroszországi Föderáció és Törökország 2010. május 12-én írt alá államközi szerződést. ${ }^{14}$ A Roszatom és leányvállalatai által épített, tengervízhütéses erőmü 4 darab VVER-1200 reaktorral fog rendelkezni, kapacitása 4800 MW lesz. Az első reaktor az előzetes tervek szerint 2023-ra, a Török Köztársaság megalapításának 100. évfordulójára lesz üzemképes. A reaktorok tervezett üzemideje 60 év, amely további 20 évvel meghosszabbítható. A finanszírozást tekintve, a mintegy 22 milliárd dolláros

10 Petrol Piyasası 2017 Yılı Sektör Raporu, [online], 2017, T. C. Enerji Piyasası Düzenleme Kurumu. Forrás: Epdk.org.tr [2019. 03. 24.]

11 A török kőolajpiacot várhatóan át fogja rajzolni, hogy 2018 októberében megnyitották az azeri állami olajvállalat (SOCAR) építette STAR olajfinomítót Izmirben. A finomító évi 10 millió tonna nyersolaj feldolgozását teszi lehetővé. Ez mintegy harmadával növeli Törökország teljes finomító kapacitását. A külső függőség csökkentése mellett a törökök az új olajfinomítótól évi 1,5 milliárd dollár megspórolását remélik. Can SEZER: RPT-STAR oil refinery to reduce Turkey depence on imports, says Erdogan, [online], 2018. 10. 19. Forrás: Reuters.com [2019. 03. 24.]. A beruházásnak közvetlen orosz vonatkozása is van: a finomítót részben orosz kőolajjal látják majd el. A SOCAR 2018 szeptemberében írt alá megállapodást a Rosznyefttel évi 1 millió tonna nyersolaj szállításáról.

12 Delivery statistics - Gas supplies to Europe, [online], 2018. Forrás: Gazpromexport.ru [2019. 03. 24.]

13 Bár a sajtóban több helyen megjelent, hogy az incidens következményeként függesztették fel a Török Áramlat vezeték építését, valójában nem ez történt. Ankara már 2015 júliusában bejelentette a tárgyalások átmeneti felfüggesztését a BOTAŞ és a Gazprom között kialakult árvita miatt. Gareth Winrow: Turkey and Russia: The Importance of Energy Ties, Insight Turkey, 19. évf., 2017/1, 17-32. o.

14 Az államközi megállapodást megelőzően, 2008-ban a törökök először pályázatot írtak ki az Akkuyu atomerőmű megépítésére, azonban - elsősorban a török ragaszkodás miatt a befektetői szempontból nem túl vonzó BOT finanszírozási modellhez - csupán egyetlen ajánlat érkezett, az orosz Atomsztrojexporttól. A tendert végül törölték. 
beruházás az úgynevezett $\mathrm{BOO}$ (Build, Own, Operate)-modell keretében valósul meg, vagyis a Roszatom építi, (többségi) tulajdonolja és üzemelteti az erőművet. A megkötött orosz-török kétoldalú megállapodás értelmében a Roszatom részesedése nem csökkenthető $51 \%$ alá. $^{15}$

Az energiavásárlási megállapodás (Power Purchase Agreement) 15 éves fix árat határoz meg, ami 12,35 cent/kWh. Ez idő alatt a török állami nagykereskedő TETAŞ (Török Villamosenergia-kereskedelmi és Szerződő Társaság) vállalja, hogy megvásárolja az első két reaktor által termelt villamos energia 70\%-át, továbbá a harmadik és negyedik reaktor esetében annak 30\%-át. Ez a fix ár és időtartam hivatott biztosítani a projekt megtérülését. A 15 év letelte után a teljes termelést a piacon értékesítik, ami után a profit $20 \%$-a a török államot illeti meg. ${ }^{16}$

Az orosz gazdaság gyengélkedése miatt a Roszatom jelenleg befektetőket keres az erömü 49\%-os tulajdonjogának megvásárlására. A sokáig esélyes török Cengiz-Kolin-Kalyon konzorcium 2018 februárjában vonult ki a tárgyalásokból. ${ }^{17}$ Alexander Novak orosz energiaügyi miniszter azt nyilatkozta, befektetők híján egyedül is megépítik az Akkuyu erőművet. ${ }^{18} \mathrm{~A}$ finanszírozási nehézségek ellenére az építési munkálatok haladnak. Az alapozási-betonozási munkát az első reaktornál 2019. március 14-én fejezték be. ${ }^{19} \mathrm{~A} 2023$-as céldátum ezzel együtt optimista - az engedélyeztetési folyamatok elhúzódása miatt valószínüsíthető a projekt csúszása.

Az oroszok a kétoldalú megállapodás értelmében 2011 óta részt vesznek a török szakemberek, a majdani Akkuyu erőmű dolgozóinak képzésében is. 2019 februárjáig több mint 85 török szakértő szerzett diplomát a moszkvai Nemzeti Nukleáris Kutatási Egyetemen (MEPhI), valamint további 140-en tanulnak jelenleg szakirányú orosz egyetemeken. ${ }^{20}$

\section{Értékelés}

$\mathrm{Az}$ orosz atomerőmű egyszerre jelent lehetőséget és kihívásokat Törökország számára. Segíti a török energiamix diverzifikálását, növeli az energiabiztonságot, csökkenti a károsanyag-kibocsátást, valamint pénzt spórol az országnak. Emellett a BOO-konstrukció jelenti az elérhetó legalacsonyabb kockázatvállalást a piacon; a kockázatok terhét a kivitelező viseli. Ezzel egy időben azonban az Akkuyu erőmű nem járul hozzá a beszerzési források diverzifikációjához, sőt erős kontrolljogokat nyújt Oroszországnak. A függés különösen az erőmü beindulásának kezdeti időszakában, a betanulás éveiben erős. A kitettséget ugyanakkor a másik oldalról csökkenti a Nemzetközi Atomenergia Ügynökség felügyelete, a helyi török mérnökök fokozatos tapasztalatszerzése, a piac nyújtotta lehetőség a nukleáris

\footnotetext{
15 Erinç ERCAN - Horst SchneIder: Turkey's way to nuclear energy - An example for a newcomer's new build, Atw Internationale Zeitschrift fuer Kernenergie, 58. évf., 2012/10, 584-592. o.

16 Uo.

17 Turkish consortium of Cengiz, Kolin and Kalyon pulls out of Akkuyu nuclear project, [online], 2018. 02. 06. Forrás: Dailysabah.com [2019. 03. 24.]

18 Russia capable of building Akkuyu plant without partners: Minister, [online], 2018. 04. 06. Forrás: Hurriyetdailynews. com [2019. 03. 24.]

19 Basemat of Turkey's Akkuyu 1 completed, [online], 2019. 03. 14. Forrás: World-nuclear-news.org [2019. 03. 24.]

20 Over 50 Turkish experts to work at Akkuyu Nuclear JSC, [online], 2019. 02. 25. Forrás: Dailysabah.com [2019. 03. 24.]
} 
üzemanyag más forrásból történő beszerzésére, illetve önmagában az a megfontolás, hogy a Roszatomnak nem érdeke a jövőbeli potenciális ügyfelek elijesztése. ${ }^{21}$

Ankara három atomerőmű építését tervezi a közeljövőben. Az elsőt a dél-törökországi Akkuyuban, a másodikat a Fekete-tenger partján, Sinopban, a harmadikat pedig a bolgár határhoz közeli İğneada területén. A sinopi erőmü megépítésére kiírt tendert 2013-ban egy japán-francia konzorcium nyerte meg. Az erőmű a BOT (Build, Operate, Transfer) modell alapján müködött volna, és az eredeti tervek szerint 2023-ban állt volna müködésbe az első reaktor. Sajtóhírek szerint azonban 2018 végén a japán cég (Mitsubishi Heavy Industries) finanszírozási gondok miatt - a kivitelezési költségek a fukusimai katasztrófa után bevezetett plusz biztonsági intézkedések szükségessége, valamint a török líra gyengülése miatt az eredetileg tervezetthez képest kétszeresükre nőttek - visszalépett a projektből. ${ }^{22} \mathrm{~A}$ harmadik erőmű építését szintén kétségek lengik körül, elsősorban az amerikai Westinghouse közelmúltbeli (2017-es) csődje miatt - igaz, a vállalat azóta (2018-ban) tulajdonosváltást és átszervezést követően sikeresen kikerült a csődvédelmi eljárás alól. A Törökország európai részén épülő erőmü a Westinghouse és a kínai State Nuclear Power Technology Corporation (SNPTC) vállalat együttmüködésében valósulhatna meg, amiről 2014-ben kezdték meg a tárgyalásokat. ${ }^{23}$

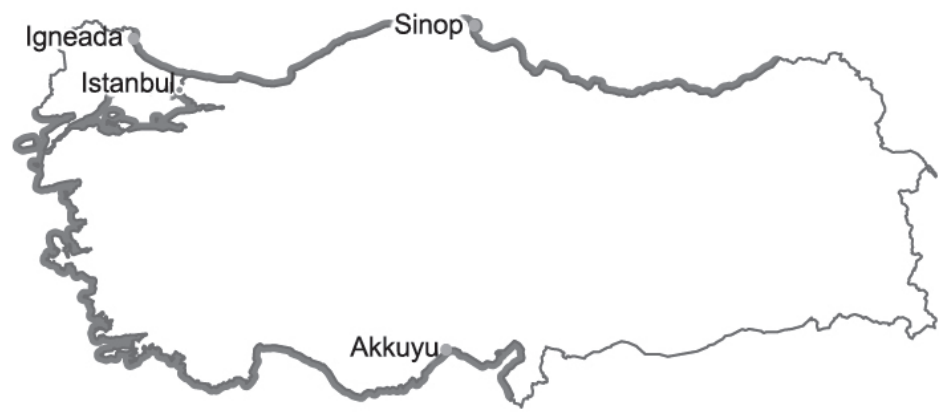

1. ábra: A tervezett törökországi atomerőművek helyszíne

Forrás: Nuclear Power in Turkey, [online], 2018. Forrás: World-nuclear.org [2019. 03. 24.]

Törökország tehát egyértelműen megpróbált diverzifikálni, és különböző partnereket bevonni a török nukleárisenergia-kapacitások kiépítésébe. Az eredeti török tervek szerint nem orosz túlsúly, hanem a három erőmüvel verseny alakult volna ki a piacon. A nyugati vállalatok gyengélkedése miatt azonban úgy tünik, a globális nukleáris piac lényegében Oroszország és Kína kezében van. ${ }^{24}$ Ezt mutatja az is, hogy Moszkva nemcsak Törökországban épít atomerőművet, hanem többek között az Európai Unión belül is: a finn parlament 2010-ben szavazta meg egy orosz erőmű építését a Hanhikivi-félszigeten - igaz,

\footnotetext{
21 The world relies on Russia to build its nuclear power plants, [online], 2018. 08. 02. Forrás: Economist.com [2019. 03. 24.]

22 Takashi Tsuj: Japan to scrap Turkey nuclear project, [online], 2018. 12. 04. Forrás: Asia.nikkei.com [2019. 03. 24.]

23 MENR - Igneada Nuclear Power Plant - Kirklareli Province - Project Profile, [online], 2019. Forrás: Marketresearch. com [2019. 03. 24.]

24 The world relies on Russia to build its nuclear power plants, i. m.
} 
az engedélyeztetési folyamat elhúzódása miatt csak 2021-ben várható az építkezés megindulása ${ }^{25}$-, és Magyarországon is orosz közremüködéssel épül Paks II.

\section{Török Áramlat}

Jelenleg kettő török-orosz földgázvezeték üzemel. Az első, még szovjet-török földgázvezeték, az úgynevezett Nyugati Útvonal (vagy Transzbalkáni vezeték) megépítése - amelynek nyomvonala a mai Ukrajna, Moldova, Románia és Bulgária területén keresztül halad - 1986 októberében kezdődött meg, egy 1984-ben aláírt szovjet-török szerződés alapján. A Nyugati Útvonal jelenlegi, kibővített kapacitása évi 14 milliárd m³. A második, orosz területről induló gázvezeték, a Kék Áramlat megépítéséről 1997-ben írtak alá a felek megállapodást. A 16 milliárd m³ éves kapacitású földgázvezeték 2003 óta üzemel.

Az Oroszország és Ukrajna (2006, 2008, 2009, 2014), valamint Oroszország és Fehéroroszország $(2004,2007,2010)$ közötti sorozatos gázviták hatására Moszkva a „megbízhatatlan” tranzitországokat kiváltó új tranzitútvonalat keresett. 2007 és 2014 között úgy tünt, a török szárazföldi területeket elkerülő, a Fekete-tengerből Bulgáriában partra lépő Déli Áramlat épülhet majd meg. Az Európai Unióval folyó viták ${ }^{26}$ miatt azonban Moszkva végül a Déli Áramlat helyett a Török Áramlat megépítése mellett döntött. Ez egyértelmüen pozitív fejlemény volt Törökország számára, hiszen egyrészt ezáltal közvetlenül orosz forrásból juthat földgázhoz, másrészt az orosz döntés megkerülhetetlen tranzitországgá tette Törökországot, ezáltal növelte Ankara politikai súlyát az európai államokkal szemben. A Török Áramlat így két célt is szolgál: 1. növeli a török ellátásbiztonságot azáltal, hogy lehetővé válik az Ukrajnán keresztül Törökországot elérő Nyugati Útvonal gázvezeték kiváltása; és 2 . Törökország közelebb kerül az energiaelosztó-központtá (hubbá) válás tervének megvalósulásához. ${ }^{27}$

Ankara és Moszkva a szerződést a Török Áramlatról 2016. október 10-én írta alá. A hozzávetőlegesen 7 milliárd dolláros beruházás keretében az orosz Gazprom két párhuzamosan futó, egyenként 15,75 milliárd $\mathrm{m}^{3}$ kapacitású csővezetékszálat épít. A mintegy 1100 km hosszú vezeték 900 km-es Fekete-tenger alatti szakasza az oroszországi Anapából indul, és a törökországi Kiyıköynél lép partra. ${ }^{28} \mathrm{~A}$ tengeri szakasz építését 2018. november 19-én fejezték be. A két vezetékszálból az egyik - amely a tervek szerint 2019 végén lép működésbe - a török fogyasztók energiaigényének kielégítését célozza, a másik szállítana tovább földgázt Európába. ${ }^{29}$

25 Finnish-Russian nuclear reactor pushed back to 2028, [online], 2018. 12. 23. Forrás: Reuters.com [2019. 03. 24.]

26 A vita egyik fó forrása az Európai Unió 2009-ben elfogadott, úgynevezett harmadik energiacsomagja, amely a földgázpiac liberalizációját célozza. Az új jogszabályok egyik legfontosabb eleme a „tulajdonosi szétválasztás” elve, vagyis a gázkitermelési és -szállítási (hálózatüzemeltetési) tevékenység szétválasztásának követelménye. Nem ez volt azonban a vita egyetlen eleme. Bővebben lásd: NóGRÁDi György - VIRÁG Attila: A Déli Áramlat projekt lezárása az orosz stratégia nézőpontjából, Külügyi Szemle, 14. évf., 2015/1, 30-50. o.

27 Türkiye’nin Enerji Stratejisi, [online], 2008, Török Köztársaság Külügyminisztériuma. Forrás: Mfa.gov.tr [2019. 03. 24.]; Kozma Tamás: Az energiatranzit szerep, mint Törökország regionális hatalmi képességeit befolyásoló tényező, Mediterrán és Balkán Fórum, 11. évf., 2018/1, 2-21. o.

28 Bővebb információk a projektről a Török Áramlat (TurkStream), illetve a Gazprom weboldalán [2019. 03. 24.]

29 Erre vonatkozóan több projektötlet is van az asztalon. Ezek közül az egyik legutóbbi a „Déli Áramlat Lite” terve, mely Bulgárián és Szerbián keresztül szállítana földgázt Magyarországra. Szép csendben döntött Putyin - Jóváhagyásával több ezer milliárdos üzletbe nyúlhat bele Magyarország, [online], 2018. 12. 01. Forrás: Portfolio.hu [2019. 03. 24.] 


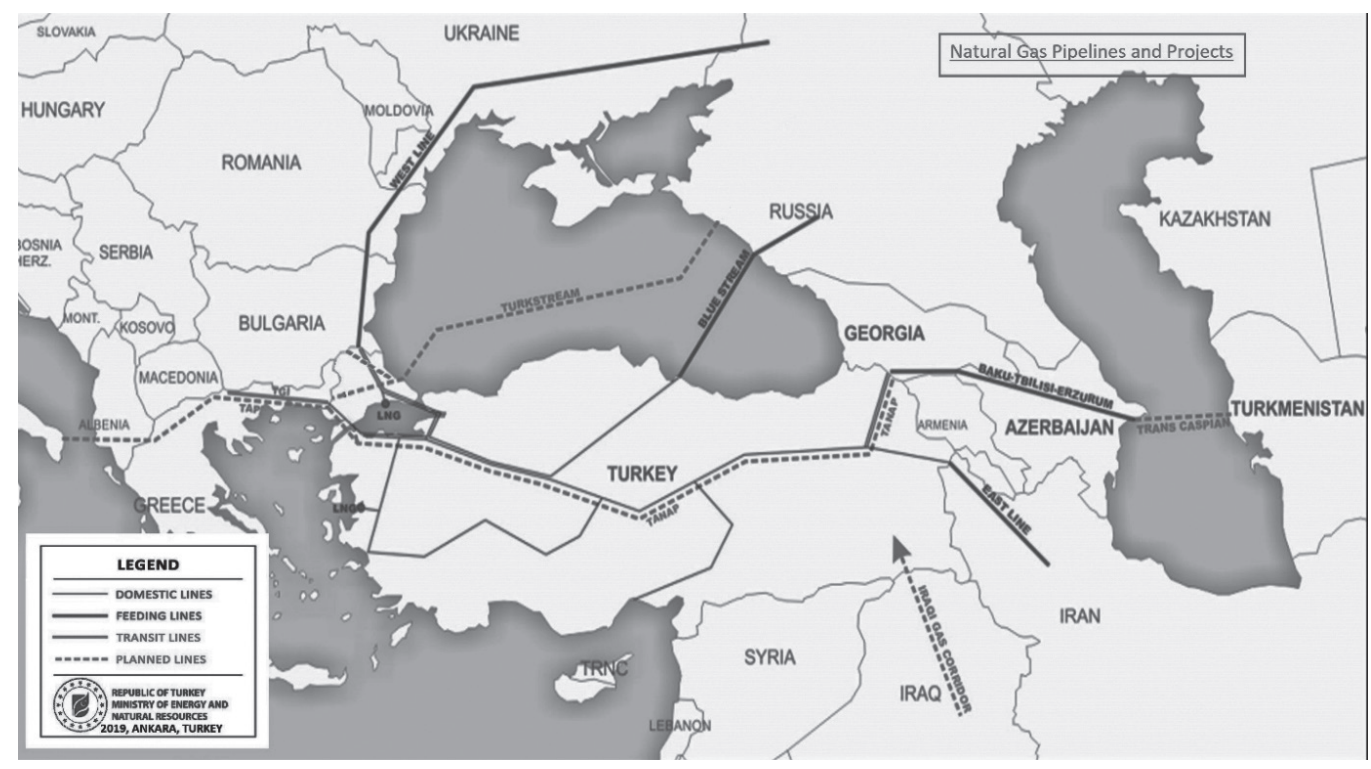

\section{2. ábra: Földgázvezetékek és -projektek Törökország környezetében}

Forrás: Natural Gas Pipelines and Projects, [online], 2019. Forrás: Enerji.gov.tr [2019. 03. 24.]

\section{Értékelés}

A sajtóban kevésbé hangsúlyozott, ugyanakkor fontos elem, hogy a Török Áramlat első szála a Nyugati Útvonal vezetéket fogja kiváltani, ${ }^{30}$ amely utóbbinál „mindössze” évi 1,75 milliárd $\mathrm{m}^{3}$-rel nagyobb a kapacitása. Ilyen értelemben tehát az oroszoktól való török gázfüggőséget jelentős mértékben nem növeli.

Moszkvának szüksége van megbízható tranzitpartnerekre a földgáz eljuttatásához az európai piacokra. A Gazprom így végeredményben - ha megindul a második vezetékszálon keresztül az európai export - ugyanúgy függeni fog a török tranzittól, mint a törökök az orosz importtól. ${ }^{31}$ A törökök megpróbálhatják felhasználni a tranzitszerepet arra, hogy árkedvezményt kapjanak Moszkvától, mint ahogyan azt a Török Áramlat engedélyezéséért cserébe sikerült kiharcolniuk (egy 10,25\%-os gázárcsökkentést a 2015-2016-os évre vonatkozóan). ${ }^{32}$

Törökország nem az egyetlen európai kötődésű állam, amely egy közvetlen orosz földgázvezetéken keresztül igyekszik energiaigényét kielégíteni. Azt követően, hogy a közösségi gázirányelv módosításával az Európai Unió lehetővé tette Németországnak

30 Murat Temizer: TurkStream to take over gas transit from Western Line, [online], 2017. 03. 15. Forrás: Aa.com.tr [2019. 03. 24.]

31 Igaz, az ukrán csővezeték megmarad vész esetére, ezáltal műszaki értelemben kiváltható a török vezeték.

32 A törökök 2015 elején kezdtek tárgyalni az együttműködési megállapodásban beígért kedvezményről a Gazprommal. A török állami kőolaj- és gázvállalat BOTAŞ 2015 októberén nyújtott be keresetet a Nemzetközi Kereskedelmi Kamarához. 2018 májusában retroaktív megegyezés született: visszamenőlegesen összesen egy milliárd dollárt kaptak a törökök. 
az 55 milliárd $\mathrm{m}^{3}$ éves kapacitású Északi Áramlat 2 megépítését, a Törökországot érő nyugati kritikák a kettős mérce percepcióját növelik. ${ }^{33}$

Az Európai Unió Déli Gázfolyosó projektje keretében megvalósuló TANAP-TAP gázvezeték, ${ }^{34}$ bár fontos mérföldkő, egyelöre biztosan nem képes kiváltani az orosz földgázt. A 2018 júniusában átadott TANAP kezdeti kapacitása „mindössze” évi 16 milliárd $\mathrm{m}^{3}$ lesz (vesd össze például Törökország 50 milliárd, illetve az Európai Unió 480 milliárd m³ -eséves gázfogyasztásával), amelyböl 6 milliárd $\mathrm{m}^{3}$ van fenntartva Törökország számára, és a hátralévő 10 milliárd $\mathrm{m}^{3}$ lesz az európai export. Ez a kapacitás nem fog drasztikus változáshoz vezetni sem a török földgázimport szerkezetében, sem a regionális energiakereskedelmi status quóban. ${ }^{35}$

\section{Összegzés}

Törökország jelentős mértékben függ az orosz energiától. Legnagyobb mértékben az orosz földgáztól. Az utóbbi években azonban Ankara tudatosan igyekszik csökkenteni a földgáz arányát a török energiamixben, ezáltal az aszimmetrikus függés mértékét is. A folyamatot nehezíti az ország folyamatosan növekvő energiaszükséglete. A folyamatban lévő projektek (az Akkuyu atomerőmű és a Török Áramlat földgázvezeték) várhatóan nem fognak drasztikus átrendeződéshez vezetni a török energiapiacon, illetve az Oroszországtól való török függés mértékében. Rövid és középtávon Törökországnak nincs más lehetősége energiaszükségletének kielégítésére, mint az együttmüködés az oroszokkal. Ez az együttmüködés ugyanakkor elsősorban kényszer; önmagában nem jelenti a török külpolitika a Nyugattól eltávolodó, stratégiai fordulatát. Adottságaiból (hazai energiahordozók szűkössége, kiválthatatlan orosz függés, egyedülálló geopolitikai és geostratégiai helyzet) Ankara lehetőségeihez mérten igyekszik előnyt kovácsolni, legyen szó - a kockázatokért mintegy cserébe - kedvezményes gázár kiharcolásáról az oroszoktól, engedmények szerzéséről az Európai Uniótól, vagy a tranzitból származó bevételek növeléséről.

\section{FELHASZNÁLT IRODALOM}

Basemat of Turkey’s Akkuyu 1 completed, [online], 2019. 03. 14. Forrás: World-nuclear-news.org [2019. 03. 24.]

Delivery statistics - Gas supplies to Europe, [online], 2018. Forrás: Gazpromexport.ru [2019. 03. 24.]

Doğal Gaz Piyasasi 2017 Yılı Sektör Raporu, [online], 2017, T. C. Enerji Piyasası Düzenleme Kurumu. Forrás: epdk.org.tr [2019. 03. 24.]

DuDLÁK Tamás: Törökország helye az Európai Unió, Oroszország és Azerbajdzsán közti gázjátszmában, Világpolitika, 2. évf., 2017/1, 60-90. o.

ERCAN, Erinç - SCHNEIDER, Horst: Turkey's way to nuclear energy - An example for a newcomer's new build, Atw Internationale Zeitschrift fuer Kernenergie, 58. évf., 2012/10, 584-592. o.

33 Gustav Gressel: Negative energy: Berlin's Trumpian turn on Nord Stream 2, [online], 2019. 02. 27. Forrás: Ecfr.eu [2019. 03. 24.]

34 A Kaszpi-térségből a korábbi zászlóshajó Nabucco-projekt helyett a török-azeri államközi megállapodás alapján megvalósult Transzanatóliai gázvezeték (TANAP) juttat majd földgázt Oroszországtól függetlenül Európába. A TANAP folytatásaként a Transzadriai vezeték (TAP) fogja továbbítani a gázt Görögországon és Albánián keresztül Olaszországba.

35 Kozma Tamás: Transzanatóliai Gázvezeték: 3.., 2.., 1.., start!, [online], 2018. 06. 27. Forrás: Ajtk.hu [2019. 03. 24.] 
Finnish-Russian nuclear reactor pushed back to 2028, [online], 2018. 12. 23. Forrás: Reuters.com [2019. 03. 24.]

Gressel, Gustav: Negative energy: Berlin's Trumpian turn on Nord Stream 2, [online], 2019. 02. 27. Forrás:

Ecfr.eu [2019. 03. 24.]

Kozma Tamás: A török-orosz kapcsolatok energiadiplomáciai aspektusai. In: BARANYI Tamás Péter

- SzÁLKaI Kinga (szerk.): Újhold. A török külpolitika útkeresése a 21. század elején, Antall József

Tudásközpont, 2016, 166-187. o.

Kozma Tamás: Az energiatranzit szerep, mint Törökország regionális hatalmi képességeit befolyásoló tényező, Mediterrán és Balkán Fórum, 11. évf., 2018/1, 2-21. o.

Kozma, Tamás: Diversification Dilemmas in Turkey's Natural Gas Imports, Asian Journal of Middle Eastern and Islamic Studies, 11. évf., 2017/11, 90-106. o. DOI: https://doi.org/10.1080/25765949.2017.12023303

Kozma Tamás: Transzanatóliai Gázvezeték: 3.., 2.., 1.., start!, [online], 2018. 06. 27. Forrás: Ajtk.hu [2019. 03. 24.]

MENR - Igneada Nuclear Power Plant - Kirklareli Province - Project Profile, [online], 2019. Forrás:

Marketresearch.com [2019. 03. 24.]

Natural Gas Pipelines and Projects, [online], 2019. Forrás: Enerji.gov.tr [2019. 03. 24.]

NóGRÁDI György - VIRÁG Attila: A Déli Áramlat projekt lezárása az orosz stratégia nézőpontjából, Külügyi Szemle, 14. évf., 2015/1, 30-50. o.

Nuclear Power in Turkey, [online], 2018. Forrás: World-nuclear.org [2019. 03. 24.]

Over 50 Turkish experts to work at Akkuyu Nuclear JSC, [online], 2019. 02. 25. Forrás: Dailysabah.com [2019. 03. 24.]

Petrol Piyasası 2017 Yılı Sektör Raporu, [online], 2017, T. C. Enerji Piyasası Düzenleme Kurumu. Forrás: Epdk.org.tr [2019. 03. 24.]

Russia capable of building Akkuyu plant without partners: Minister, [online], 2018. 04. 06. Forrás: Hurriyetdailynews.com [2019. 03. 24.]

SEZER, Can: RPT-STAR oil refinery to reduce Turkey depence on imports, says Erdogan, [online], 2018. 10.

19. Forrás: Reuters.com [2019. 03. 24.] DOI: https://doi.org/10.1080/10245330512331389782

Szép csendben döntött Putyin - Jóváhagyásával több ezer milliárdos üzletbe nyúlhat bele Magyarország, [online], 2018. 12. 01. Forrás: Portfolio.hu [2019. 03. 24.]

Temizer, Murat: TurkStream to take over gas transit from Western Line, [online], 2017. 03. 15. Forrás: Aa.com.tr [2019. 03. 24.]

The world relies on Russia to build its nuclear power plants, [online], 2018. 08. 02. Forrás: Economist.com [2019. 03. 24.]

ToNGORI Zsófia: A Török Áramlat gázvezeték és Törökország vezetékes gázszállításban rejlő potenciális lehetőségei. Energiabiztonsági dilemmák a Török Áramlat gázvezetékkel kapcsolatban, Hadtudományi Szemle, 10. évf., 2017/1, 168-183. o.

Total Primary Energy Supply (TPES) by source, Turkey 1990 - 2016, [online], 2019. Forrás: Iea.org [2019. 03. 24.]

TsujI, Takashi: Japan to scrap Turkey nuclear project, [online], 2018. 12. 04. Forrás: Asia.nikkei.com [2019. 03. 24.]

Tunc, Zeynel - Altunyuva, Aslı Kehale: Oil and gas regulation in Turkey: overview, [online], 2018. 09. 01. Forrás: Ca.practicallaw.thomsonreuters.com [2019. 03. 24.]

Turkey’s energy import bill up 15.6 percent in 2018, [online], 2019. 02. 06. Forrás: Hurriyetdailynews.com [2019. 03. 24.]

Turkey's Energy Profile and Strategy, [online], 2019. Forrás: Mfa.gov.tr [2019. 03. 24.]

Turkey's thermal coal receipts from Russia fell by 16pct in 2018, [online], 2019. 02. 27. Forrás: Steelguru.com [2019. 03. 24.]

Türkiye’nin Enerji Stratejisi, [online], 2008, Török Köztársaság Külügyminisztériuma. Forrás: Mfa.gov.tr [2019. 03.24.]

Turkish consortium of Cengiz, Kolin and Kalyon pulls out of Akkuyu nuclear project, [online], 2018. 02. 06. Forrás: Dailysabah.com [2019. 03. 24.]

Winrow, Gareth: Turkey and Russia: The Importance of Energy Ties, Insight Turkey, 19. évf., 2017/1, 17-32. o. 